\title{
Labeling of Products from the Context OF ENVIRONMENT, QUALITY AND SAFETY
}

\author{
Rusko, M., KraliKova, R., MiKulova, M. \& IlKo, J.
}

Abstract: The policy is focused on the product itself, produced activity or a service offered, however, not only in their final appearance (e.g. as finalized product), but during all life cycle phases, i.e. projection, composition decision, production phase, usage and the final phase - disposal. Subjects of this process comprise high number of stakeholders - market members: producers, distributers, trade, consumers, but also the state. Eco-design, environmental labelling of the products, life cycle assessment, green marketing are important tools of the environmentally oriented policy and environmental management. This paper describes the voluntary tools, which are elaborated and implemented consensually and these predict the future development and quality increase of the environmental labelling programmes to a high extent.

Key words: environment, product, policy, ecolabelling, ecodesign
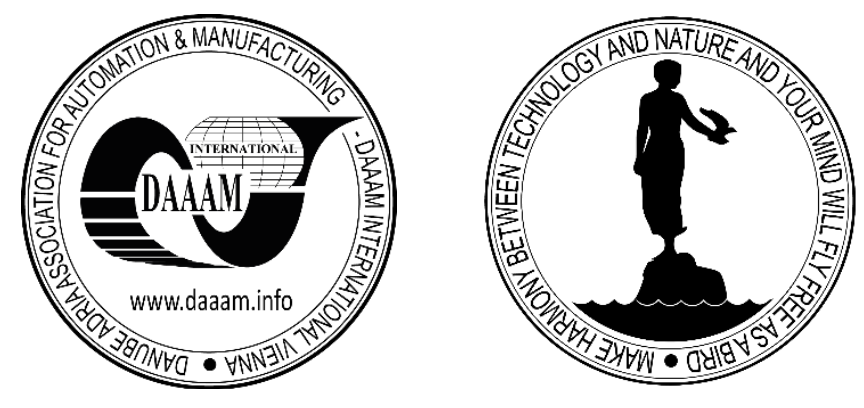

Authors' data: doc. Ing. PhD. Rusko, M[iroslav]*; doc. Ing. PhD. Kralikova, R[uzena]**; Ing. Mikulova, M[onika]*; Ing. Ilko, J[an]*, *Slovak University of Technology in Bratislava, UIBE, Trnava, Slovakia, ** Technical University of Kosice, Letna 9, 04200 Kosice, Slovakia, miroslav.rusko@ stuba.sk, ruzena.kralikovavtuke.sk, monika.mikulova@stuba.sk, jan.ilko@stuba.sk

This Publication has to be referred as: Rusko, M[iroslav]; Kralikova, R[uzena]; Mikulova, M[onika] \& Ilko, J[an] (2016). Labeling of Products from the Context of Environment, Quality and Safety, Chapter 37 in DAAAM International Scientific Book 2016, pp.419-434, B. Katalinic (Ed.), Published by DAAAM International, ISBN 978-3-902734-09-9, ISSN 1726-9687, Vienna, Austria

DOI: $10.2507 /$ daaam.scibook.2016.37 
Rusko, M.; Kralikova, R.; Mikulova, M. \& Ilko, J.: Labeling of Products From the ...

\section{Introduction}

Linking of environmental issues to economy and finance is an important sphere. Growing load and deterioration of the environment can be interpreted as a result of some external effects interventions. While the positive externalities influence the positive productional and utilizational functions of other subjects, the negative externalities influence the negative ones. Both types of external effects can act as parcial or global externalities.

From the analysis of different ways of the environmental protection in 80's of the last century arose that the most effective and the most economic ways of the environmental protection are based on prevention, then a research and a liquidation of causes, which evocate the contamination of the environment. (Cascio et al, 1996).

The application of this preventive strategy for the production processes conduced to the formation of the cleaner production. The cleaner production fixated to the research and liquidation of the environment devaluation causes, which the production processes effect. By reason of the production processes are to a certain extent defined by the character of produced product, the centre of environmental policy coverage removed from the production processes to the next cause of the environment devaluation, so on the product and it began formulate so-called environmentally oriented product policy. The European Commission has been placing an emphasis on promoting the so-called Integrated Product Policy (IPP) that aims to support the realisation of environmental product innovations in order to achieve a broad reduction of all environmental impacts along a product's life cycle.

Environmental attention in the last decade has seen a shift away from production facilities and processes to products and their impact on the environment across their life cycle. Eco-efficiency, eco-design, product-oriented environmental management systems (poems), sustainable service strategies, product stewardship, supply chain management, eco-innovation and Integrated Product Policy (IPP) are all examples of concepts that have become popular within the business sector as well as with policymakers. Although all these concepts have a sometimes minimal difference in focus, they all have the same aim - to reduce the impact of products and services on the environment. Two of these concepts, eco-innovation and IPP, can be seen as two sides of the same coin. Eco-innovation is the response from industry and the academic community to the challenge of sustainable product development whereas IPP is the answer from governments. (Nuij, 2001)

Contemporary teaching, research and process innovation is directly connected with most up-to-date information, solutions and testing opportunities. In process analysis, improvement or reorganization for production planning, supply chain engineering, production or transport logistics, knowledge-driven innovation derives from best opportunities of testing and simulations.

In the era of information technology, the computer-based simulations are tools of teaching and planning. 


\section{Pressure of Rising Demand and Using the Market}

Our behaviour makes huge demands on the planet. The 20th century, the world increased its use of fossil fuels by a factor of 12 and extracted 34times more material resources. Demand for food, animal feed and fiber may increase by $70 \%$ by 2050 . If we carry on using resources at the current rate, we will need more than two planets to sustain us. By its nature, the environment transcends political, legal and man-made boundaries.

The underlying aim is to improve the quality of the environment, protect human health, achieve prudent and rational use of natural resources, and promote international measures to address global or regional environmental problems.

A coordinated environmental strategy across the Union ensures synergies and coherence between EU policies and, given the relevance of environmental legislation for many business sectors, will ensure a level playing field for their activities and prevent obstacles undermining the single market.

Many take the environment for granted, but pressure on the Earth's finite resources is growing at an unprecedented rate. Efforts must be made to raise general awareness, use resources more efficiently and eradicate damaging and wasteful behaviour. Otherwise, future generations will be deprived of their legitimate inheritance. This requires collective action involving the EU, national, regional and local governments, businesses, NGOs and ordinary individuals.

The major environmental challenges facing Europe have evolved since the early days of European environmental policymaking. In the 1970s and 1980s the focus was on traditional environmental themes such as protecting species and improving the quality of the air we breathe or the water we drink by reducing emissions of pollutants. Now, emphasis is on a more systematic approach that takes account of links between various themes and their global dimension. This means moving from remediation to prevention of environmental degradation.

It involves ensuring that other areas such as agriculture, energy, transport, fisheries, regional development, research, innovation and external aid take fully into account the environmental consequences of their policy and funding decisions. This mainstreaming will ensure a more coherent approach towards environmental challenges and maximize synergies.

The market is one cost-effective way to protect and improve the environment and ease pressure on scarce resources. Taxes and subsidies can be used to act as incentives or deterrents to persuade companies and consumers to opt for greener manufacturing methods and products.

\section{Encouraging Eco-innovation}

Eco-innovation is any form of innovation aiming at, or resulting in, significant and demonstrable progress towards the goal of sustainable development, by reducing impacts on the environment, enhancing resilience to environmental pressures or achieving a more efficient and responsible use of natural resources. 
Rusko, M.; Kralikova, R.; Mikulova, M. \& Ilko, J.: Labeling of Products From the ...

Environmental technology industries are already an important part of the EU economy. However, with the exception of renewable energy, eco-innovation has penetrated markets relatively slowly. Bottlenecks include the failure of market prices to accurately reflect environmental costs and benefits, and incentives and subsidies that sustain wasteful practices and rigid economic structures. The EU's Eco-Innovation Action Plan highlights the specific drivers of eco-innovation and barriers to its uptake. Support is available to finance research, innovation and eco-innovative companies. (Rehfeld et al, 2007)

At the beginning of 2004, the European Union adopted the Environmental Technology Action Plan (ETAP) to improve the development and wider use of environmental technologies. These are defined as those technologies whose use is less environmentally harmful than relevant alternatives. The definition of environmental technology refers to environmentally sound technologies as stated in Chapter 34 of Agenda 21: Environmentally sound technologies protect the environment, are less polluting, use all resources in a most sustainable manner, recycle more of their wastes and products, and handle residual wastes in a more acceptable manner than the technologies for which they were substitutes".

Implementing the ETAP will entail various actions, one of which involves improving testing and performance verification related to environmental technologies. In this respect, the objective would be to provide a European framework for verifying the performance characteristics of new environmental technologies through commonly recognised and transparent protocols.

Early in 2004, the European Union adopted the Environmental Technology Action Plan (ETAP) to improve the development and wider use of environmental technologies, defined as "all technologies whose use is less environmentally harmful than relevant alternatives". One of the priority actions of the ETAP is entitled "Establishing European Networks of technology testing, performance verification and standardisation". To encourage greater take-up of green technologies, the EU is promoting green public procurement, costing products over their life-cycle and ecolabelling. (Figure 1).

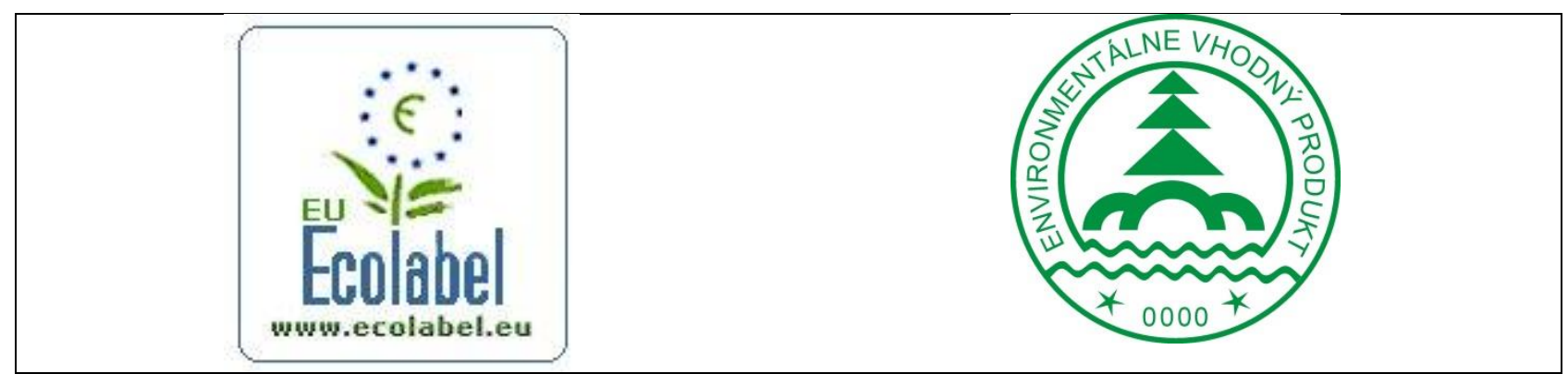

Fig. 1. Mark EU-Ecolabel and Slovak- Ecolabel mark

\section{Environmental Oriented Product Policy}

In environmental policy, it is increasingly accepted that more emphasis should be placed on consumption and its implications from the point of view of the environment. Another relatively new feature is the focus on products. At the policy level, this 
perspective is known as product-oriented environmental policy or, in brief, product policy. This approach is closely related to the idea of product chain thinking, which means recognizing the fact that environmentally relevant decisions are made at all stages during the products' life cycle, from raw material extraction to consumption and beyond. (Niva \& Timonen, 2008)

Growing humane population raises its material and energetic consumption and threatens overrun of carrying-capacity of our planet. Global environmental and safety problems manifest their retrogressive trend. In the present there are carried on discussions at all levels of management about safety implications of climatic changes and migration, about terrorism, about cybernetic safety, about dangerous diseases transfer etc. There is an effort to analyse situation arisen or potential risks and to adopt adequate measures.

The topic of climatic changes is becoming increasingly urgent. It is implied that the cause behind environmental degradation is mainly energy production, while little or no attention is paid to its use.

Environmental sustainability issues include resource efficiency, dematerialization, reduction of waste and emissions leading to improved environmental performance and/or reduced environmental impact (Pujari, 2006). "Our Common Future", a report published by the World Commission for Environment and Development presided by Gro Harlem Brundtland, defines sustainable development as the kind of development that meets the needs of the present without compromising the ability of future generations to meet their own needs. The report does not want to forecast continuously worsening environment, on-going poverty and difficulties in an increasingly polluted world where resources will continue to disappear. In the report, the World Commission presented its urgent and pressing warning based on the latest and best scientific evidence that the time to implement necessary measures has come to ensure resources for this and future generations. The report does not offer a detailed implementation plan but has showed a path where world's nations may extend their mutual cooperation (Miklencicova, 2015).

Many enterprises do no work with sustainability within corporate strategy and management, and neither do they include sustainability in performance measurement and management. Sustainability should become an integral part of strategic management and corporate planning. Sustainable development is incorporated in the Slovak legal system as the kind of development that preserves the possibility for current and future generations to satisfy their basic needs while not reducing the natural diversity and maintaining the natural functions of ecosystems (Article 6 of Act No. 17/1992 Coll. on the environment).

The objective of the environmentally oriented product policy is a reduction of the potential environmental impact of products to a level, which will be acceptable from the point of view of sustainable development. Organizations of all kinds are increasingly concerned with achieving and demonstrating sound environmental performance by controlling the impacts of their activities, products and services on the environment, consistent with their environmental policy and objectives. They do so in the context of increasingly stringent legislation, the development of economic policies and other measures that foster environmental protection, and increased concern 
Rusko, M.; Kralikova, R.; Mikulova, M. \& Ilko, J.: Labeling of Products From the ...

expressed by interested parties about environmental matters and sustainable development.

Environmental product policy is in general determined by the relationships between its aims - subjects - objects - tools. It is based on the integrated approach to the product life cycle, which anticipates an enormous amount of information. It has to solve the questions of the international trade as well as the rules of the International Trade Organization. The objective of this policy is a reduction of the potential environmental impact of products to a level, which will be acceptable from the point of view of sustainable development. It means:

- Highest possible raw material exploitation

- Energy consumption minimization

- Achieving of such product quality, which will allow for prolongation of the life span of product, its increased usefulness, waste emission reduction to an acceptable level

- Environmental risk minimization linked to the product disposal after reaching its life span.

The policy is focused on the product itself, produced activity or a service offered, however, not only in their final appearance (e.g. as finalized product), but during all life cycle phases, i.e. projection, composition decision, production phase, usage and the final phase - disposal. Subjects of this process comprise high number of stakeholders - market members: producers, distributers, trade, consumers, but also the state.

Environmental labelling of the products, environmental profile, life cycle assessment are important tools of the environmentally oriented policy and environmental management. (Kotraus,2003). The life cycle approach is a beginning at the phase of eco design of a product, and it is a systematic integration of the environmental views during the whole process of development and production. The development phase comprises several steps, since market situation analysis, via innovation search and their evaluation, up to implementation. Economic analyses emphasize, that the product development gives up to $70 \%$ of its final price. It means that the following number of degrees of freedom to the resulting influence to the costs structure is relatively low for a serial production (Pfeiffer,1983). Rubik, Petchow and Scholl assume that the environmental impacts of a product are influenced by the development process to the same extent. Thus, product design becomes a key issue focused on development of such parameters, which will minimize or eliminate negative impacts to the environment even before its placement to the market (Rubik, et al., 1995).

Product policy results from the main elements, giving its conceptual development, political elaboration and implementation, i.e. aims and strategy, tools, subjects and products. All those main elements influence selection of the parameters, which are supposed to minimize or eliminate negative environmental effects of a product. Environmental product policy aims and strategy are focused to the sustainable development principles at present, as they were defined by the report „Our Common Future" (Brundtland G.H. (1991) and confirmed by the Rio summit in 1992. Certain 
change of the model concepts appears at present as described by the following Table 1 .

\begin{tabular}{|c|c|}
\hline $\begin{array}{l}\text { Flow-through } \\
\text { management }\end{array}$ & $\begin{array}{l}\text { - Environmentally designed substance flows } \\
\text { - Reduction of the product amount used in a } \\
\text { time period }\end{array}$ \\
\hline $\begin{array}{l}\text { Enormous material } \\
\text { consumption }\end{array}$ & $\begin{array}{l}\text { - Effectiveness of the material change } \\
\text { Reduction of the dangerous substances } \\
\text { amount, } \\
\text { - Raw material replacement } \\
\text { - Production technology change }\end{array}$ \\
\hline Product orientation & - Function orientation \\
\hline $\begin{array}{l}\text { Curative } \\
\text { environmental care }\end{array}$ & - Preventive environmental care \\
\hline $\begin{array}{l}\text { Natural resources - } \\
\text { capital consumption }\end{array}$ & $\begin{array}{l}\text { - Long term sustainability of resources } \\
\text { - Renewable as well as non-renewable ones }\end{array}$ \\
\hline Nature control & - Orientation to the harmony with nature \\
\hline $\begin{array}{l}\text { Consuming and } \\
\text { disposal mentality }\end{array}$ & $\begin{array}{l}\text { - Mentality appreciating values } \\
\text { - Better products } \\
\text { - Environmental impact minimization } \\
\text { - Separation and recycling of waste }\end{array}$ \\
\hline
\end{tabular}

Tab.1. Change of the model concepts in the environmental policy.

Broadening trends of the indirect tools and emphasis to the voluntary information tools appear in the environmental product policy. These tools are extensively based on the voluntary activities of the producers, as well as increased environmental awareness of the public. Systems of environmental evaluation and labelling are implemented, which claim that the product (in concordance with the recent knowledge) process parameters minimizing or eliminating its negative environmental impacts (Hricova, Lumnitzer, Pinosova \& Goga Bodnarova, 2016). Implementation of such systems results not only from initiatives and requirements of the state administration, but also from the engagement of the producers and consumers.

The questions of different ecolabelling programmes development are dealt by several important international organizations, e.g. International Chamber of Commerce - ICC, World Trade Organization - WTO, United Nations Environmental Programme - UNEP, who assess and investigate the implemented environmental labelling programmes and who also evaluate their efficiency and effectiveness. The results achieved show that well organized programmes of environmental evaluation and labelling may serve as an effective tool not only for the environmental protection policy, but also for the trade policy.

The decisive factors are quality, compatibility, transparency and trustability of the programmes, increase of the environmental awareness of the producers, consumers as 
Rusko, M.; Kralikova, R.; Mikulova, M. \& Ilko, J.: Labeling of Products From the ...

well as the public, information availability, and mutual acceptance of the programmes in the international frame.

In recent times, the European Commission (EC) has been placing an emphasis on promoting a so-called Integrated Product Policy (IPP). IPP as defined by the EC aims to support the realisation of environmental product innovations in order to achieve a broad reduction of all environmental impacts along a product's life cycle (EU, 2001). The background is that all industrial goods cause environmental degradation in some way, whether from their manufacturing, use or disposal. Initiatives concerning IPP are largely due to the fact that traditional additive environmental protection has increasingly reached technical and economic limits. Moreover, increasing importance of the phases of consumption and disposal could be observed compared to the phases of extraction of raw materials and the production process. Due to the heterogeneity of products, IPP cannot just consist of one general policy instrument, of course. Instead, there is a whole variety of measures that can be used to achieve the IPP objective, e.g., standards or so-called soft environmental policy instruments such as activities regarding voluntary agreements or environmental labelling. Concerning the latter, some companies already apply some of these voluntary environmental organisational measures. Indeed, despite the Green Paper on IPP published by the EC, which outlines proposals for the promotion of an IPP, it is still not well understood which factors and environmental policy instruments influence the environmental performance of products in general (EU, 2001 and EU, 2003), and thus environmental product innovations in particular (Rehfeld, Rennings \& Ziegler, 2007).

\section{Importance of Ecodesign, LCA and Environmental Labelling}

Ecodesign, ecolabelling, LCA and green marketing are voluntary regulative tools of environmetal policy. Term a voluntary tool indicates, that his using is not ordered by the legislation and that it depends only on enterprise, if it decides for the application of some of these tools of not (Rusko, 2005). Concerning that the public environmental awareness is still spreading, so now on the market should not come the products, by which already in the product development, production, using and follow disposal were not dealed with the minimalization of negative impacts to the environment. The term a regulative tool of environmental policy means, that the tool's application prevents to certain release of negative impact of new product on the environment (by the comparison with the impact of natural old product minimal).

Currently the customers question companies as to under what conditions their products have been produced and whether the used raw materials and procedures are environmentally safe and harmless to the health of workers. They demand to know as to in what way it is going to be possible to recycle the cover of the product as well as the product itself, or destruct it after its life cycle has terminated [4]. Firms must respect all Slovak and foreign legal aspects, regulations and norms coinciding either directly or indirectly with environment. Firms are able to evaluate the best as to what extent the legislature enables them to carry out their voluntary obligations. Therefore, a whole number of significant companies in addition to their systems of quality management implement also environmental management systems. They are based on the 
implementation of elements of formation and protection of environment into their decision-making processes (Hyrslova,2004).

Prior to the implementation of new products in the market, it is very important to prepare the market itself. This process is to be carried out in coincidence with each new product. In case of ecolabelling it is possible to use the advantage of the fact that ecolabels guarantee a minimum negative impact on environment, and therefore the behaviour of customers can indirectly affect the quality of environment, or help the customers to conceive better the offer of products with comparable properties and functionalities (Brundtland,1991).

\section{Life-Cycle Assessment}

The LCA (Life-Cycle Assessment) method is one of the most important information tools for environmental policy. It is used for determining adverse environmental impacts of any system (product or service). Information that is provided by the LCA method enables both experts in ecodesign and enterprise marketing to select new products and employees of the state administration and in the area of ecolabelling to stipulate regulations and criteria for the support of environmentally friendly products. Last but not least, this information is significant for further scientific and technical development as it releases the causes of harmful effects on the environment. The LCA method can then be summarily defined (according to ISO 14040) as: compilation and evaluation of the inputs, outputs and the potential environmental impacts of a product system throughout its life-cycle.

When using the LCA method, it must be acknowledged that the life-cycle of a specific product can consist from various substance and material flows in each individual case. It should be emphasized that the concept of a ,product life-cycle ,is not identical with the concept of the "service life of a product". The service life of a product is the period during which a product can be used for the purpose for which it was manufactured and thus constitutes only a small part of the life-cycle of a product.

The LCA method is an irreplaceable, analytically oriented information instrument for the integrated product policy which can be utilized in practice, in particular, in:

- Decision-marking concerned with development of products and processes in enterprises

- Decision-making on purchase of goods

- Ecolabelling

- Decision-making related to statutory regulations

- Support for legislative decisions

Life cycle assessment (LCA) has been recognized in the EU in the context of 'Integrated Product Policy' (IPP) as providing "the best framework for assessing the potential environmental impacts of products currently available." Compared with other environmental management tools and assessment methods, LCA does in fact place a special emphasis on consumption. In the LCA model, all environmental impacts are measured per functional unit (e.g., a wash of laundry, a cup of coffee), and are thus 'caused' by the act of consuming that unit.( Nissinen et al., 2007) 
Rusko, M.; Kralikova, R.; Mikulova, M. \& Ilko, J.: Labeling of Products From the ...

When engineers, designers or environmental managers today address the environmental burdens of products, it is almost self-evident that they consider some kind of a life cycle approach. That is, they direct their attention not only at product composition, or at the processing stage that they themselves are involved with, but at the whole physical life cycle of the product, from raw materials to end-of-life. In principle, LCA could thus be an extremely empowering tool for consumers. The LCA model can connect small, everyday consumer decisions to their impacts on different environmental problems, and to environmental burdens occurring in distant times and places. (Heiskanen, 2002)

\section{Ecodesign}

The eco-design is a systematic process of design and development of a product, that apart from the classic properties as a functionality, economically, security, ergonomically, technical feasibility, aesthetically, a so one, accentuates on the achievement of minimal negative impact of a product on the environment namely in term of whole life cycle. The estimate of the environmental profile of a product has a significant role, it's a specification of all significant factors, by which the product effects on the environment during its whole life cycle.

The life cycle approach is a beginning at the phase of eco design of a product, and it is a systematic integration of the environmental views during the whole process of development and production. The development phase comprises several steps, since market situation analysis, via innovation search and their evaluation, up to implementation. Economic analyses emphasize that the product development gives up to $70 \%$ of its final price. It means that the following number of degrees of freedom to the resulting influence to the costs structure is relatively low for a serial production. Thus, ecodesign becomes a key issue focused on development of such parameters, which will minimize or eliminate negative impacts to the environment even before its placement to the market (Rusko \& Balog, 2003).

The ecodesign is one of the important prevention oriented voluntary regulative tools of the environmental policy. The preventive bearing of the ecodesign is given by that the request for the release of negative impact of a product on the environment is integrated already to the product reflections beginning, so it's going on the most preventive and in term of the practise the most economic approach to the release of negative impacts of products on the environment (Remtova,2003). The advantage of the ecodesign is, that his using is also like a cleaner production in the competence of the company sphere.

Eco-innovation aims to develop new products and services that are not based on redesign or incremental changes to existing products but rather on providing the consumer with the function they require, in the most eco-efficient way. Clearly, attention has to be given to both sides of the ecoefficiency spectrum. The majority of companies, especially small and medium-sized enterprises (SMEs), have never heard of ecodesign let alone eco-innovation. Consumers are still almost never informed about the environmental impact of their buying decisions. There is still a lot to be done. However, by not addressing at the same time the, admittedly more difficult, challenges 
posed by the need for 'eco-innovative' products and services, the EU risks missing out on the enormous potential for innovation and development. Not to mention the risk of missing out on sustainable development.(Heiskanen, 2002)

\section{Ecolabelling}

Ecolabelling is a voluntary method of environmental performance certification and labelling that is practised around the world. An "ecolabel" is a label which identifies overall, proven environmental preference of a product or service within a specific product/service category. There are different classifications of label. In contrast to "green" symbols, or claim statements developed by manufacturers and service providers, the most credible labels are based on life cycle considerations; they are awarded by an impartial third-party in relation to certain products or services that are independently determined to meet transparent environmental leadership criteria (Polankova et al., 2015). The ISO 14020 series of standards provides businesses with a globally recognized and credible set of international benchmarks against which they can prepare their environmental labelling, which is increasingly used on products and in advertising, in response to consumer demand. With the relentless focus on climate change and health, consumers are becoming more interested in less tangible product attributes such as the ethical and environmental aspects of a product's production and supply. In response to this, manufacturers often voluntarily choose to provide information concerning the environmental aspects of their products on labelling and in advertising. At the start of its work, the ISO subcommittee responsible for the development classified different types of labelling by type number. The two main types already in existence were:

- The "classic" ecolabelling schemes, which award a mark or a logo based on the fulfilment of a set of criteria - these were identified as Type I environmental labelling

- Claims which were made by manufacturers and businesses, and could be seen as being "self-declared" - these were identified as Type II self-declared environmental claims.

In addition, however, it was recognized that a third type was starting to emerge which consisted of a formalized set of environmental data describing the environmental aspects of a product. These declarations were identified as Type III environmental declarations. Several current successful programmes are used in compliance with business rules based on the principle of voluntarism, as e.g. ecolabelling, i.e. labelling of environment-friendly products and services being more inoffensive toward the environment than their substitutes. Its main aim is to support the preservation of the environment and prevention of pollution in balance with social and economic needs. The term ecolabelling/ecolabelling system refers to a certification system ruled by a third independent party, i.e. neither by the producer or the customer.

Germany was the first country to introduce environmental labelling after 1977. Similar systems have been gradually introduced also in other countries. In 1994, Global Ecolabelling Network (GEN) was formed. Within the wide class of environmental 
Rusko, M.; Kralikova, R.; Mikulova, M. \& Ilko, J.: Labeling of Products From the ...

labelling and declarations in coincidence with products or services, there are labels with various extent of relation to environment or its compounds. They can be divided into several types:

- Standardised in the framework of ISO/TC/207 (series of standards 14020), type I., II. or type III.

- Standardised out of scope of ISO 14020

- Non-standardised

- Labelling with environmental aspects - standardised

- Labelling with environmental aspects - non-standardised.

Ecolabelling is a significant compound of environmental product policies that are generally determined by relations between their targets - objects - subjects - tools (Cascio, 1996). Ecolabelling is based on an integrated approach to life cycles of products, the fact of which assumes provision of significant information. It is focused on products or provided services, however not only on their final form of completed products but also on individual phases of their life cycles. The subjects of this process are represented by a number of market participants, namely producers, distributors, dealers, customers, including the state (Rusko \& Ambros, 2002).

\subsection{Questionary surveys}

To find out the awareness of consumers about the eco-labels in the Slovak Republic, more surveys were carried out in the years (2004-2015). (Rusko \& Volakova, 2004; Rusko \& Kralikova, 2013). The most complex survey was carried out in the year 2016. The structure of respondents according the gender was 560 women and 490 men, according regions (Table 2), and divided by age (Table 3 ).

\begin{tabular}{|l|l|}
\hline Region & \\
\hline Bratislava & 195 \\
\hline Trnava & 161 \\
\hline Nitra & 135 \\
\hline Trenčín & 122 \\
\hline Žilina & 106 \\
\hline Banská Bystrica & 108 \\
\hline Prešov & 101 \\
\hline Košice & 122 \\
\hline
\end{tabular}

Tab.2. Structure of respondents according the regions

\begin{tabular}{|l|c|}
\hline Less than 15 & 0 \\
\hline $16-25$ & 227 \\
\hline $26-35$ & 276 \\
\hline $36-45$ & 162 \\
\hline $46-55$ & 135 \\
\hline $56-65$ & 148 \\
\hline More than 66 & 102 \\
\hline
\end{tabular}

Tab.3. Structure of respondents according the age 
According to the responses to the question:

- How do you overall sense any labels placed on products: we can say, that respondents generally sense labels neutrally $(40,66 \%)$, or mostly positively $(42,66$ $\%)$ to positively $(16 \%)$. The conclusion may be, that the eco-label has a chance to interest the consumer.

- Did you notice eco-labels on some products: $85,52 \%$ of respondents noticed the eco-label.

- How do eco-labels influence your purchase behavior: 36,95\% of the respondents are neither influenced, nor not influenced by eco-labels, $27,23 \%$ are mainly not influenced as well $2,85 \%$ are mainly influenced. The purchase behavior is really influenced only by $2 \%$ of the respondents.

- Do you think it would be useful to state the particular harmfulness of the product on its package: $97,04 \%$ of respondents positively answered to the question

- What do you think, propagation is deficient form what site: $33,42 \%$ consider propagation as deficient mostly from the side of producers, $28,28 \%$ consider propagation as deficient mostly from the side of state, 38,28\% consider propagation as deficient mostly from the side of business companies.

The results of this question approve results of surveys made in this area show that presentation of products awarded by eco-label and National programme of environmental assessment and labelling in the Slovak Republic is not efficient (Rusko \&Chovancova, 2008).

\section{Conclusions}

This paper tests the awareness of consumers about the eco-labels as one of voluntary tools of environmental policy in the Slovak Republic.

This study builds on past research by looking specifically at how are reactions of customers to the problems of environmental level of products. Based on questionnaire surveys and other research the fundamental right of every consumer should be availability of necessary information to protect their own health. Information should be obtained from the marks referred to the product which it comes into contact. Marks are an integral part of everyone's life. We can see various types of marks at home, in stores and everywhere around us. Symbols indicate the importance assigned to them in opinion system (labeling scheme) to the consumer.

Ecodesign, LCA, ecolabelling and green marketing as a voluntary regulative tools of the environmental policy are significant instrument for the increase of abilities of the organization competitive (Rusko \& Kralikova, 2013).

Their using is important for the organizations with established EMS by ISO standards 14000, thus EMAS, which contracted to the continual release of negative impacts of its activities on the evironment. Abroad, during the period of its existence, ecolabelling has entered not only the minds of customers, but also became an inevitable part of advertisements of producers and importers introducing appropriate brands of environment-friendly products into the market. Products available on the market 
Rusko, M.; Kralikova, R.; Mikulova, M. \& Ilko, J.: Labeling of Products From the ...

should be healthiness and should not threaten human life and the overall safety of the consumer and does not pollute the environment. This means that security specifications and standards have to exist and to be adopted by each country for any product. Consumers must be protected from any damage that could be caused by the product.

Based on the knowledge the consumer creates an own personal value of product quality which helps during the process of making decision about buying the product. All external and internal features and characteristics of the product affect the consumer behavior. Important role in consumer behavior is a safety and environmental labeling and brand. Provides a means of receiving the relevant information for the purpose of mediation of knowledge. Basic right of every consumer's need for information to enable it to protect their own health. Information obtained from the brands mentioned on the product with which it comes into contact.

Supervision and inspection the market is more and more difficult. It has to be clear that products situated in the market and stores are not absolutely risk free. Not sufficient or incorrect information can be present on the product which can endanger the customer's health.

Despite the fact that in SR there was no campaign about the ecolabelling programme it is sensible to label the products because it strengthens the feeling of the public about the environmental protection. By means of environment-friendly product labelling the Slovak customers get guaranteed information about the products respecting the environment. The role of successful implementation of environmental label in Slovakia is especially the provision and availability of information about the products.

Future research could look at the specific role of supervision and inspection the market that products situated in the market and stores are not absolutely risk free. Not sufficient or incorrect information can be present on the product which can endanger the customer's health and environmental safety.

Future research could look at the specific role of supervision and inspection the market that products situated in the market and stores are not absolutely risk free. Not sufficient or incorrect information can be present on the product which can endanger the customer's health.

\section{Acknowledgements}

This paper was written in frame of the work on the projects VEGA 1/0990/15 The readiness of industrial enterprises to implement the requirements of standards for quality managementsystems ISO 9001:2015 and environmental management systems ISO 14001:2014(50\%)and project APVV-15-0327(50\%) solved at Technical University of Kosice.

\section{References}

Brundtland G.H. (1991). Our common future, Prague, p. 297 (in Czech) Cascio, J. ; Woodside,G. ; Mitchell, P. (1996) ISO 14000 Guide. New York 
Hyrslova, J. (2004) Benefits of Environmental Management Systems in the Czech Republic. In.: Conference Akademicka Dubnica 2004. Dubnica. pp. 163 - 166, ISBN 80-227-2076-3

Kotovicova, J. et al. (2003) Clean Production. Brno: MZLU. ISBN 80-7157-675-1 (in Czech)

Kotraus, A. (2003) Customer Relationships Management as Key factor of Success. Eurozpravodaj 2/2003, Plzen, ISSN 1213-6913

Pfeiffer,W. (1983) Strategisch orientiertes forschungs und Entwicklungsmana-gement - Probleme und Losungsansatze aus Sicht der Wissenschaft. In: Forschungs - und Entwicklungsmanagement, Stuttgart, pp. $124-133$

Remtova, K. (2003): Ecodesign. Prague: Ministry of Environment of the Czech Republic. p.15. ISBN 80-7212-230-4

Miklencicova, R. (2015) Perception of environmental product labelling by Slovak consumers. Procedia Economics and Finance 34 ( 2015 ) pp. 644 - 648

Rubik, F., Petschow, U., Scholl,G. (1995): Basic characteristics of the ecological product policy. Heidelberg, Berlin (in Czech)

Rusko, M. \& Ambros, J.(2002). Ecolabelling as a Part of the Environmentally Oriented Product Policy in the Slovak Republic. In.Visegrad Agenda 21-Transition from Centrally Planned Economy to Sustainable Society? Prague. pp.272-275, ISBN 80-901914-8-7

Rusko, M. \& Balog, K. (2003). Ecolabelling in the Slovak republic. In CO-MAT-TECH 2003 Conference, Trnava. ISBN 80-227-1949-8

Polankova, M., Manlig, F. \& Kralikova, R. (2015). Environmental reporting in the enterprise and related issues. In. MM Science Journal, 10/2015, pp. 691-695.

Wenzel,H., Hauschild, M. \& Alting, L. (1997): Environmental Assessment of Products. London. Chapman \& Hall. p. 533. ISBN 0-412-80800-5

Environmental labels and declarations. How ISO standards help. ISO Central Secretariat, Geneve, 2012, ISBN 978-92-67-10586-4, 25 p

What Is Ecolabelling. Available on URL: Accesed on:2008-08-15 http://www.globalecolabelling.net/what_is_ecolabelling/index.htm

Hricova, B., Lumnitzer, E., Pinosova, M. \& Goga Bodnarova, A. (2016). Life-cycle assessment of product through of the SWOT analysis. Production Management and Engineering Sciences, ESPM 2015, pp. 89-94

Niva,M. \& Timonen, P. (2008) The role of consumers in product-oriented environmental policy: can the consumer be the driving force for environmental improvements? International Journal of Consumer StudiesVol. 25(4), pp. 331-338, ISSN: $1470-6431$

Rehfeld, K. Rennings, M. \& Ziegler, A.(2007): Integrated product policy and environmental product innovations: An empirical analysis. Ecological Economics, Vol.61(1), pp. 91-100

Pujari, J.(2006). Eco-innovation and new product development: understanding the influences on market performance. Technovation, Vol.26(1), pp. 76-85, ISSN: 0166-4972

Nissinen, A., Grönroos, J. , Heiskanen, E., . Honkanen, A., Katajajuuri, J.-M., Kurppa, S.et al. (2007) Developing benchmarks for consumer-oriented life cycle assessment- 
Rusko, M.; Kralikova, R.; Mikulova, M. \& Ilko, J.: Labeling of Products From the ...

based environmental information on products, services and consumption patterns. Journal of Cleaner Production, ISSN: 0959-6526, Vol.15(6). pp. 538-549,. Heiskanen, E. (2002): The institutional logic of life cycle thinking. Journal of Cleaner Production, ISSN: 0959-6526, Vol.10 (5), pp. 427-437

Nuij R. (2001) Eco-innovation: Helped or hindered by Integrated Product Policy. The Journal of Sustainable Product Design, Vol. 1(1). pp 49-51. ISSN: 1367-6679

Rusko, M. \&Chovancova, J. (2008). Consumers`awareness about eco-labels type I. In. Environmental Management for Education and Edification. Vol.5(2), pp. 23-34. ISSN 1336-5762

Rusko, M. (2005). Life cycle assessment, ecodesign, ecolabelling and green marketing as a voluntary regulative tools of the environmental oriented product policy. In. International Journal for Theory and Practice in Environ-mental Management for Education and Edification. Vol.2(2), pp.61-71. ISSN 1336-5762

Rusko, M. \& Kralikova, R. (2013) Implementation of environmental oriented monitoring in the manufacturing company. In.Advanced Materials Research Volume 816-817, pp. 1225-1230

Rusko, M. \& Volakova, M. (2004). Survey on utilization of environmental labelling and LCA in Slovakia. In. Environmental Labelling. 2/2004, Praha, pp. 6-7, ISSN 12124761 